\title{
Sex Education Has a Positive Impact on Children's Self Concept
}

\author{
Sri Widayati ${ }^{1, *}$ Wulan P. Saroinsong ${ }^{1}$ Wagino $^{2}$ Reinita A. Syarifa ${ }^{1}$ Al-Dedek D. \\ Yanna ${ }^{1}$ Intan R. Pratiwi ${ }^{1}$ \\ ${ }^{1}$ Department of Early Childhood Education Teacher Education, Universitas Negeri Surabaya, Indonesia \\ ${ }^{2}$ Department of Special Education, Universitas Negeri Surabaya, Indonesia \\ *Corresponding author. Email: intan.19088@mhs.unesa.ac.id
}

\begin{abstract}
Sex education for children is an effort made to provide understanding, teaching, and planting about issues related to sexuality given to children. The purpose of this study was to determine the self-concept that has a positive impact on children and to find out how to instill sex education in early childhood in a good and right way. This study uses a quantitative approach using descriptive statistics. The results of this study reveal that most parents already understand the importance of inculcating sex education in children, which will positively impact children's self-concepts.
\end{abstract}

Keywords: Parents, Children, Sex Education.

\section{INTRODUCTION}

Sex education is an effort made to understand (knowledge and values) that study about physical-genetic and its functions as well as the differences between men and women. Sex education is the planting, teaching, and knowledge of issues related to sexuality given to children. In sex education, there are efforts to keep children from the direction of sex where children do forbidden things in religion, direction, and understanding of sex from physical and psychological health and spiritual aspects.

Finkelhor, Hammer, and Sedlak [1] stated that approximately one in seven girls and one in seven boys would experience sexual abuse in childhood. Most of them will never tell anyone about what they have experienced; this is usually due to threats or manipulation by the perpetrator. As a result, there is an increasing number of cases of sexual harassment around us, but only a few cases can be revealed from the many cases that have occurred.

Lack of understanding of children about sexual abuse and lack of understanding of parents about the importance of sexual education for children make them only silent or have been abused. With discussions, guidance, and directions related to sex, it is very important to give children.

According to Montessori, early childhood is a sensitive period; it is at this time that early childhood is very easy to accept stimuli from the surrounding environment because at that time the ability of the brain of early childhood to receive all knowledge from the surrounding environment is accompanied by a strong curiosity is very high. Children's curiosity covers all areas that they find fun and interesting, one of which is related to sex [2].

The purpose of efforts to prevent sexual abuse of children in the field of education or sex education is to identify dangerous situations and prevent sexual harassment, as well as teach children about forms of touch that are harmful and bad, how to refuse or refuse or refuse end interactions with the perpetrator or just a suspicious person, as well as how to ask for help [3].

Sex education will instill various kinds of behavior in which children can form their own identity or "selfconcept." Various kinds of self-concepts can be embedded if the child has been given direction about sex education, which will positively impact the child. The self-concept itself will be formed when the child understands gender differences that have been given direction from more mature people than the child. The word gender itself comes from English which means "gender" in Webster's New World Dictionary states that gender is the visible difference between men and women from behavior, gender is a cultural concept that makes a difference in terms of different behavior, mentality a man and a woman, and emotional between a man and a woman [4]. 
When a child understands the concept of gender differences, a self-concept will grow in the child himself, like a child being embarrassed when entering a toilet that is not by their gender or other things. This applies to children, which results in positive things for children. Children recognize positive sex education from an early age, so when children grow up, they will already have their self-concept; children know the boundaries according to their gender.

\section{METHODS}

Recent studies have shown the relationship between sex education and its positive impact on children's selfconcept. As follows:

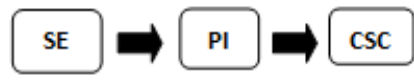

Figure 1 Relationship between sex education and its positive impact on children's self-concept

"Note: SE: Sex Education, PI: Positive Impact, CSC: Child's Self Concept

This latest study took a questionnaire from parents of children aged 1-6 years spread from several cities. This questionnaire was distributed to parents via Google Form. Arikunto[5] stated that if the subject is less than 100 people should be taken all, if the subject is large or more than 100 people can be taken $10-15 \%$ or $20-25 \%$ or more. The total population in this study amounted to 280 people, so the sample used is 280 , which is the total sample of the total population that is the subject of the study, in line with the opinion that the sample which is equal to the total population is often called the total sample.

The type of research used in this research is quantitative research. Quantitative research methods are: "A research method that uses data processing in the form of numbers as a tool to analyze and conduct research studies, especially regarding what has been studied". Where this quantitative research explains the relationship between variables, tests the theory to be studied. This method is also very systematic, planned, and structured so that research design can be done in detail from the start.

In the use of statistical analysis techniques where inferential statistics is a statistical technique used to analyze sample data, and the results are used to calculate the population [6]. In inferential statistics, there are parametric and non-parametric statistics. Parametric statistics require that many assumptions be met. The main assumption is that the data to be analyzed must be normally distributed. In regression, the assumption of linearity must be met so that the data obtained from the research results are tested for normality and linearity before being used to test hypotheses.

The sampling technique in this study used a stratified random sampling technique. According to Sugiyono [6], this technique is used if the population has members/elements that are not homogeneous and proportionally stratified. Margono [7] states that stratified random sampling is commonly used in populations that have a stratified or layered arrangement.

From the results of 200 journals obtained, it is explained that sexual education of children is very important at this time, not only supervising children, but by providing provisions on sex education from an early age when children are still minors Sex education is also very influential on the formation of children's character in the future. Therefore, our group took the title "Sex Education has a Positive Impact on Children's Self Concepts" to understand parents better and take part in providing an understanding of the importance of sex education in early childhood.

\section{RESULTS AND DISCUSSION}

Descriptive statistical analysis is used to describe the data that has been collected. Commonly used descriptive statistics include frequency calculations, range (high or low score or value), suggestion, mode, median score, and standard deviation. This study aims to describe demographic, independent, and dependent variables displayed in the data below. 
Table 1. Demografic information

\begin{tabular}{|c|c|c|c|}
\hline \multicolumn{2}{|l|}{ Variable } & \multicolumn{2}{|c|}{$(N=280)$} \\
\hline & & \multirow{2}{*}{$\frac{n}{5}$} & \multirow{2}{*}{$\frac{\%}{1.7}$} \\
\hline Parents Age & $17-20$ years & & \\
\hline & $21-25$ years & 35 & 11.2 \\
\hline & $26-30$ years & 51 & 17.8 \\
\hline & $31-35$ years & 125 & 43.8 \\
\hline & $36-40$ years & 27 & 9.4 \\
\hline & $>40$ years & 45 & 15.7 \\
\hline \multirow[t]{6}{*}{ Child Age } & 1 years & 17 & 5.9 \\
\hline & 2 years & 14 & 4.9 \\
\hline & 3 years & 16 & 5.6 \\
\hline & 4 years & 32 & 11.2 \\
\hline & 5 years & 136 & 47.7 \\
\hline & 6 years & 70 & 24.5 \\
\hline \multirow[t]{2}{*}{ Child Gender } & Male & 139 & 48.8 \\
\hline & Female & 146 & 51.2 \\
\hline
\end{tabular}

From table 1 Demographic Information, it can be seen that by $43.8 \%$, the majority of parents who understand sex education which has an impact on children's selfconcept, are parents aged around 31-45 years. For the sex of the child, there is no significant difference, namely,
$51.2 \%$ are female while $48.8 \%$ are male. The average of children aged 5 years with an achievement of $47.7 \%$, which shows good understanding on how sex education gives positive impact on their self-concept.

Table 2. Mean and standard deviation

\begin{tabular}{|c|c|c|c|}
\hline \multicolumn{2}{|l|}{ Variable } & $M$ & SD \\
\hline \multirow[t]{6}{*}{ Parents Age } & $17-20$ years & 145 & 98,9 \\
\hline & $21-25$ years & 158,7 & 89,4 \\
\hline & $26-30$ years & 168 & 82,7 \\
\hline & $31-35$ years & 205 & 56,5 \\
\hline & $36-40$ years & 156 & 91,2 \\
\hline & $>40$ years & 165 & 84,8 \\
\hline \multirow[t]{6}{*}{ Child Age } & 1 years & 151 & 94,5 \\
\hline & 2 years & 149,5 & 95,8 \\
\hline & 3 years & 150,5 & 95,1 \\
\hline & 4 years & 158,5 & 89,4 \\
\hline & 5 years & 210,5 & 52,6 \\
\hline & 6 years & 177,5 & 76 \\
\hline \multirow[t]{2}{*}{ Child Gender } & Male & 212 & 51,6 \\
\hline & Female & 215,5 & 49,1 \\
\hline \multirow{2}{*}{$\begin{array}{l}\text { Parents know whats is sex education for their } \\
\text { children }\end{array}$} & Yes & 272 & 9,1 \\
\hline & No & 155,5 & 91,5 \\
\hline \multirow{2}{*}{$\begin{array}{l}\text { Parents know that sex education has a positive } \\
\text { impact on children }\end{array}$} & Yes & 266,5 & 13 \\
\hline & No & 255,5 & 20,5 \\
\hline
\end{tabular}




\begin{tabular}{|c|c|c|c|}
\hline $\begin{array}{l}\text { Parents have instilled sex education in their } \\
\text { children }\end{array}$ & $\begin{array}{l}\text { Yes } \\
\text { No }\end{array}$ & $\begin{array}{l}255,5 \\
173\end{array}$ & $\begin{array}{l}20,8 \\
79,1\end{array}$ \\
\hline Giving sex education to children based on religion & $\begin{array}{l}\text { Yes } \\
\text { No }\end{array}$ & $\begin{array}{l}273 \\
154,5\end{array}$ & $\begin{array}{l}8,4 \\
92,2\end{array}$ \\
\hline $\begin{array}{l}\text { Children know that there are gender differences } \\
\text { in every creature }\end{array}$ & $\begin{array}{l}\text { Yes } \\
\text { No }\end{array}$ & $\begin{array}{l}273,5 \\
154,5\end{array}$ & $\begin{array}{l}8,1 \\
92,6\end{array}$ \\
\hline $\begin{array}{l}\text { Children already know their gender as } \\
\text { male/female }\end{array}$ & $\begin{array}{l}\text { Yes } \\
\text { No }\end{array}$ & $\begin{array}{l}276 \\
151,5\end{array}$ & $\begin{array}{l}6,3 \\
94,3\end{array}$ \\
\hline The child's name matches the gender & $\begin{array}{l}\text { Yes } \\
\text { No }\end{array}$ & $\begin{array}{l}282 \\
145,5\end{array}$ & $\begin{array}{l}2,1 \\
98,6\end{array}$ \\
\hline Children have implemented gender differences & $\begin{array}{l}\text { Yes } \\
\text { No }\end{array}$ & $\begin{array}{l}271,5 \\
156\end{array}$ & $\begin{array}{l}9,5 \\
91,2\end{array}$ \\
\hline Parents introduce how to protect body parts & $\begin{array}{l}\text { Yes } \\
\text { No }\end{array}$ & $\begin{array}{l}277 \\
150,5\end{array}$ & $\begin{array}{l}5,6 \\
95,1\end{array}$ \\
\hline $\begin{array}{l}\text { Children show an attitude of shame when going to } \\
\text { the bathroom with people who do not match their } \\
\text { gender. }\end{array}$ & $\begin{array}{l}\text { Yes } \\
\text { No }\end{array}$ & $\begin{array}{l}269,5 \\
158\end{array}$ & $\begin{array}{l}10,9 \\
89,8\end{array}$ \\
\hline $\begin{array}{l}\text { Children show a shy attitude when changing } \\
\text { clothes in public }\end{array}$ & $\begin{array}{l}\text { Yes } \\
\text { No }\end{array}$ & $\begin{array}{l}267,5 \\
160\end{array}$ & $\begin{array}{l}12,3 \\
88,3\end{array}$ \\
\hline $\begin{array}{l}\text { When children ask about sex, parents explain } \\
\text { according to the child's understanding. }\end{array}$ & $\begin{array}{l}\text { Yes } \\
\text { No }\end{array}$ & $\begin{array}{l}270 \\
257,5\end{array}$ & $\begin{array}{l}10,6 \\
90,1\end{array}$ \\
\hline $\begin{array}{l}\text { From an early age, parents give an understanding } \\
\text { that the child's body, from the shoulders to the } \\
\text { knees, especially the genitals, should not be } \\
\text { touched by others. }\end{array}$ & $\begin{array}{l}\text { Yes } \\
\text { No }\end{array}$ & $\begin{array}{l}277,5 \\
150\end{array}$ & $\begin{array}{l}5,3 \\
95,4\end{array}$ \\
\hline $\begin{array}{l}\text { From an early age, mothers teach their children to } \\
\text { wear decent clothes }\end{array}$ & $\begin{array}{l}\text { Yes } \\
\text { No }\end{array}$ & $\begin{array}{l}280,5 \\
147\end{array}$ & $\begin{array}{l}3,1 \\
97,5\end{array}$ \\
\hline $\begin{array}{l}\text { Parents explain to children how to clean genitals } \\
\text { from an early age }\end{array}$ & $\begin{array}{l}\text { Yes } \\
\text { No }\end{array}$ & $\begin{array}{l}276,5 \\
151\end{array}$ & $\begin{array}{l}6 \\
94,7\end{array}$ \\
\hline
\end{tabular}

Regarding the impact caused by education about sex in early childhood, this will affect self-concept in children. Because if children can understand sex, they will also understand how to take care of themselves and respect the people around them, so that children can be more careful in their actions.

Table 3. Regression test result

Table 3. Regression test result
\begin{tabular}{|l|l|l|l|l|l|}
\hline \multicolumn{1}{|l|}{ Variable } & Sum of square & df & Mean square & F i \\
\hline Regression & 812.584 & 1 & 812.584 & 492.376 & \\
\hline Residual & 467.004 & 283 & 1650 & & \\
\hline Total & 1279.628 & 284 & 814.234 & & \\
\hline $\begin{array}{l}\text { a. Dependent Variable, Zscore: Total X } \\
\text { b. Predictors: (Content), Zscore: Total Y }\end{array}$
\end{tabular}

Therefore, parents need to understand a good way to teach sex education to early childhood so that children can understand the boundaries for themselves when they are in a social environment. This, of course, will also have an impact on the future of the child. If the child has understood about sex education from an early age, the child is not curious about sexual activities that are not by his age later. 
From the output, it is known that the calculated $\mathrm{F}$ value $=492,376$ with a significance level of $0.000<0.05$, then the regression model can be used to predict the participation variable or in other words, there is an influence of the religiosity variable $(\mathrm{X})$ on the aggressiveness variable (Y). The table of regression test results shows that the variable $(\mathrm{X})$ affects the variable (Y), which explains that sex education has a positive impact on children's self-concept.

\section{CONCLUSION}

From the data that has been analyzed, it can be concluded that sex education taught to children from an early age can affect growth which has a positive impact on children's self-concept. This is also supported by broad parental knowledge and understanding of how to understand sex education for early childhood, especially for children aged 1-6 years.

In general, the age of the parents themselves also affects the way their children are educated. As much as $1.7 \%$ of the survey results of parents' age is still very young, namely 17-20 years. Which, of course, will indirectly affect the growth of children. Because at the age of 17-20 years, someone is still in his teens, which is not the time to educate a child, because medically it has been explained that the ideal age for a woman to have children is in the age range of 21-30 years. Less than 21 years of age, women are still in the adolescent stage, which is still psychologically unstable at that age. This will also affect the way parents educate their children.

\section{REFERENCES}

[1] D. Finkelhor, H. Hammer, and A. Sedlak, Sexually Assaulted Children: National Estimates and Characteristics. US Department of Justice, Office of Justice Programs, Office of Juvenile Justice and Delinquency Prevention., 2008.

[2] E. G. Hainstock, Montessori untuk prasekolah. Delapratasa Publishing, 2002.

[3] D. Finkelhor, "The prevention of childhood sexual abuse," Futur. Child., vol. 19, no. 2, pp. 169-194, 2009.

[4] R. Gonibala, "Fenomena bias gender dalam pendidikan islam," Iqra, vol. 4, 2007.

[5] S. Arikunto, Metode penelitiam. Jakarta: Rineka Cipta, 2010.

[6] Sugiyono, Metode Penelitian Pendidikan (Pendekatan Kuantitatif, Kualitatif, dan R\&B). Bandung: Alfabeta, 2010.

[7] Margono, Metodologi Penelitian Pendidikan. Jakarta: Rineka Cipta, 2004. 